\title{
Food \& beverage service practices: A study of small hotels in India
}

\author{
Sandeep Malik \\ Assistant Professor, Institute of Hotel \& Tourism Management, M.D. University, Rohtak, Haryana, India \\ *Corresponding Author: Sandeep Malik \\ Email: smalik02@gmail.com
}

\begin{abstract}
Purpose: Satisfying guests demands related to food and beverage items is one the biggest business in world economy, same is true for hotels. Hotels get a huge revenue and profit, as well, from the sale of food and beverage items to their guests. So different practices related to service of food and beverage items to guests can help a hotel in outsmarting its competition and earn huge profits. Therefore, this study tries to disclose different factors that affect food and beverage service practices in sampled hotels of India.

Design/Methodology/Approach: Likert type 5 point scale was used in questionnaire which ranged from 1 to 5; where 1 stands for Not Important at all and 5 for Very Important. The data was collected form food and beverage service managers or supervisors of the sampled hotels.

Findings: It was found that various activities related to food \& beverage control, e.g. preparation of K.O.T.'s, missing K.O.T.'s, auditing of food and beverage stores, and formally qualified staff are of prime importance for better management of food and beverage service practices in sampled hotels.

Research Limitations: The biggest limitations of the research are its universe and sample size; which may be addressed by the scholars in future.

Originality/value: The research will provide a base for further studies aiming to address food and beverage service related issues not only in hotels but also in other establishments.
\end{abstract}

Keywords: Food and beverage, Service, Menu, Hotel.

\section{Introduction}

The Indian food and beverage service industry is one of the most vibrant industries that has seen unprecedented growth in the recent past and continue to expand rapidly (KPMG, 2016). This can be attributed to changing demographics, increase in disposable incomes, urbanisation and growth of organised retail (KPMG, 2016). This has also been influenced by technology to make it one of the fastestgrowing in the world with a sale of around USD 1.3 billion and growing at about 10 per cent annually which is the growth of foodservice industry in developed country like USA (Aaron Allen \& Associates, 2017). The report also projected this to double in size by 2021. The food and beverage sector in India is extremely evolving in nature with even more evolving restaurant trends (POSIST, 2017) which accounts for approximately 31 per cent of India's consumption basket, compared to 9 per cent in the US, 17 per cent in Brazil and 25 per cent in China. It has been estimated that there are around 1.5 million eating outlets in India; out of these, only 3000 are in organised sector.

Apart from independent restaurants, foodservice outlets of hotels also contribute to this trend. These outlets are responsible for providing food and beverage items to both resident and non-resident guests of hotels. However, around a decade ago foodservice was considered as a mandatory service to hotel guests (Gunnear \& Burkhart, 1977) and profit making from this section was not the main aim. As the competition increased and rooms became almost same in different hotels; the managers started looking at and using foodservice as a unique selling proposition for distinguishing themselves from competition. This strategy paid off and now the foodservice is second highest revenue earner for hotels irrespective of their categories. In a hotel, scope of foodservice ranges from full-service fine dining restaurant to banquet.

\section{Review of Literature}

Kotschevar (1965) described that dining room facilities in commercial operations have a very short useful life. Proper merchandising potential dictates frequent changes in decor. Thus, for the dining area, we need to plan for a short life. Then why plan flooring that will last for twenty to thirty years when it will be used for only five years?

Hubsch (1966) propounded that dramatic changes have taken place in the hotel industry's attitude toward food and beverage operations in the last ten years. The most significant change in attitude has been that food and beverage has become important as a potential source of new profits.

Avery (1968) defined planning of simplified food service layout planning as an organized group approach to a food service plan. It consists of step-by-step procedures designed to integrate the best available experience and knowledge into a composite food service facility so that it will provide maximum operating efficiency in terms of manpower utilization, short product movement distances, and reduced preparation and service costs.

Ghene and Nejelski (1970) divulged that the powerful influence of technological progress upon the food service industry challenges every thinking member of this industry to make the best use of new methods and equipment. The basic menu concept and systems methodology are present to satisfy the needs of a great, growing populace that more and more demands the products it produces, More and more people, young and old, are eating and dining out. Hence, away from home eating moves into greater prominence with easy acceptance. 
Bernatsky (1971) elaborated that the human element, to my mind, is even more important to a successful operation than the physical layout and equipment. If the people have good job attitudes and good habits, your operation will he successful. If they are unhappy and disinterested, a better physical plant and standardized recipes and portions won't improve their production and service.

Powers (1976) explained that the restaurant industry of today is very much like the restaurant industry of fifteen years ago. All elements now present were present then, but the proportion has changed. In the next ten to fifteen years, a similar kind of evolution is likely to take place. It is appropriate, here, to ask, "What will the restaurant industry he like tomorrow?" And the answer is "Like it is today - only more so."

Gunnar et al (1977) illustrated that the profitable operation of food and beverage facilities is even more important to the management of a condominium hotel or motel than it is to the management of a conventional hotel. Fifty years ago, many hotel executives looked upon their food and beverage operations as a service to their guests, and were satisfied if they operated at the break-even point. More recently, a reasonable contribution to the bottom line from the food and beverage department has become the norm. While the rooms-department revenue in a conventional hotel is usually the largest contributor to house profit, the contribution of food and beverage profit to a condominium hotel management company's bottom line is of much greater significance - absolutely and as a percentage of total profitsbecause of the nature of condominium ownership and the division of the rooms rental income between management and the unit owners.

Romanelli (1978) expressed that the ability to pinpoint energy utilization is a prerequisite for the establishment of an energy-management program. A total energy audit will help determine which areas and processes are energy-intensive and merit attention. Once energy consumption of food products is determined, the energy costs can be calculated and menus priced accordingly. Should energy availability become limited, it will be possible to change to less energyintensive, more profitable products.

Lambert and Watson (1984) found that restaurant managers instinctively know that the interior design of their establishments influences their customers' behavior patterns and satisfaction levels. But instinct is insufficient to assess the specific effects of a food-service environment on customers. No design-research technique is without bias, and each technique provides different types of data, so you should generally use a variety of data-collection methods in your environmental-design study, rather than relying on one single method.

Patterson and Alvarez (1985) elucidated that most restaurant-information systems embrace the following six categories of information: (1) menu analysis, (2) F\&B inventory management, (3) labor productivity, (4) general accounting, (5) financial planning, and (6) internal control.

Cousins (1988) described that there are three distinct systems operating within a single food and beverage operation. These are namely the system for food production, the system for delivery or the service sequence, and the system for customer management or the customer process.

Riley and Davis (1992) described that as most of the profit is made on the sale of the rooms, so food and beverage has always been secondary to accommodation. But the increase in competition has forced managements to look for new sources of revenue generation and attracting guests. The profitable operation of food and beverage facilities is even more important to the management of resort hotels than it is to the management of a conventional hotel.

Palmer, Kasavana, and McPherson (1993) explicated that a pre-checking system is critical to the proper functioning of a restaurant, both as a mechanism for appropriate customer service and kitchen scheduling and as a means of internal control.

Lundberg (1994) rightly pointed out that of all resort hotel departments, food and beverage department requires greatest most attention and expertise; as meal deadlines must be met, food sanitation standards followed, customer food preferences tracked, and costs carefully controlled. $\mathrm{He}$ further added that any let down in customer service could mean losing the patronage of the guest. Walker (2009) explains that the resort hotel guests tend to stay longer than at transient hotels. This presents a challenge to the management to provide quality foods and beverages to keep the guests interested.

National Restaurant Association (1999) described that the U.S. foodservice industry is gigantic. More than 10 million workers-about 8 per cent of the total workforce-are employed in foodservice. Over 815,000 foodservice facilities operate in the United States, ranging in scope from street corner hot dog vendors to elegant full-service restaurants. The average adult eats out 192 times each year and spends 44 cents of each food dollar on meals purchased away from home. On any given day about 46 per cent of the population are foodservice patrons.

Food and beverage (or foodservice) operations are concerned with the provisions of food and a variety of beverage within business. The various elements that comprise food and beverage operations can be summarised in the catering cycle of Cracknell, Kaufman and Nobis (2000) i.e. consumer and market, formulation of policy, interpretation of demand, convergence of facilities, provisioning, production and service, control of costs and revenues, and monitoring of consumer satisfaction (Cousins, Foskett \& Gellespie, 2010).

Shiring, Jardine, and Mills (2001) found that catering is a multifaceted segment of the food service industry. There is a niche for all types of catering businesses within the segment of catering. The food service industry is divided into three general classifications: commercial segment, noncommercial segment, and military segment. Catering management may be defined as the task of planning, organizing, and controlling. Each activity influences the preparation and delivery of food, beverage, and related services at a competitive, profitable price. These activities work together to meet and exceed the customer's perception of value. 
Assaf and Matawie (2009) used data envelopment analysis (DEA) to determine the various efficiencies of Australian hospital foodservice operations. The analysis showed that the average DEA indices of technical, allocative, and cost efficiencies were $65.3 \%, 81.5 \%$, and $52.3 \%$, respectively. This indicated that allocative efficiency is more significant than technical efficiency as a source of improvement in cost efficiency. The results from the statistical model highlighted the importance of managers' education and experience in improving the level of technical, allocative, and cost efficiencies in hospital foodservice operations.

Malik and Kumar (2012) declared that all lodging properties offer food and beverage services for tourists and locals. These outlets are the second most important sources of revenue and profits for any hotel. Provisions of food and beverages also contribute toward guest satisfaction/dissatisfaction. So every up-market property prefers to have a number of restaurants rather than having only one.

Amlani (2016), President of NRAI, described that the total food services market today stands at INR 3, 09, 110 crores and has grown at $7.7 \%$ since our last report in 2013. This is projected to grow to INR 4, 98, 130 crores at a CAGR of $10 \%$ by 2021 . This year alone, the Indian restaurant sector will create direct employment for 5.8 million people and contribute a whopping INR 22, 400 crores by way of taxes to the Indian economy.

Kant (2016) India has been on a high growth trajectory over the last couple of years. India's exponential growth and consumption in terms of frequency of eating out and experimentation with cuisines and concepts has given the F\&B services sector such a fillip that this industry is currently estimated to be worth USD 48 billion in terms of overall market size.

Indian Restaurant Congress (2017) reported that India's restaurant sector, currently pegged at Rs $3,09,110$ crore ( $\$ 48$ billion), growing at a CAGR of 10 per cent to reach Rs $4,98,130$ crore by 2021 as tier-2-3 regions are set to drive growth, reports the two-day Indian Restaurant Congress 2017 held on 28th and 29th August

\section{Objective of the Study}

The literature elucidated that it is very important to manage food and beverage service outlets in a better and professional manner. This becomes more important in case of Indian hotel industry as it is still in its infancy stage and growing at a healthy pace. If hoteliers could establish different factors responsible for food and beverage practices, these could be of great help in better planning of food and beverage outlets and may guarantee success for these foodservice outlets. Therefore, this study endeavoured to distinguish factors that affect the food and beverage service practices in sampled hotels of India.

\section{Methodology}

Likert type 5 point scale was used in questionnaire which ranged from 1 to 5; where 1 stands for Not Important at all and 5 for Very Important. The variables, a total of 21, for the study were identified with the help of academicians, experts from the industry and the literature available. The data was collected from food and beverage service managers or Supervisors of the sampled hotels. 160 small hotels were approached for the study; but 109 hotels returned the filled questionnaire. This can be deemed as good response rate i.e. 68.13 per cent. The data was analysed using factor analysis with the help of PASW Statistics 18 to find out various practices that affect the food and beverage service in sampled hotels of India.

\section{Analysis}

To achieve the objective of research i.e. to study the food and beverage service practices followed in small hotels of India; factor analysis was used to reduce various variables into fewer dimensions. For this, first the suitability of the test was determined with the help of goodness of fit tests i.e. Kaiser-Meyer-Olkin (KMO) Measure of Sampling Adequacy and Bartlett's Test of Sphericity.

\section{Table 1: KMO and Bartlett's test}

\begin{tabular}{|l|c|c|}
\hline $\begin{array}{l}\text { Kaiser-Meyer-Olkin Measure of Sampling } \\
\text { Adequacy. }\end{array}$ & 0.619 \\
\hline $\begin{array}{l}\text { Bartlett's Test of } \\
\text { Sphericity }\end{array}$ & Approx. Chi-Square & 858.464 \\
\cline { 2 - 3 } & df & 210 \\
\cline { 2 - 3 } & Sig. & 0.000 \\
\hline
\end{tabular}

The value of KMO was 0.619 which can be considered as good for conducting factor analysis. This was supported by a significant value of Bartlett's Test of Sphericity at given degree of freedom (Table 1).

Kaiser normalization rotation method of factor analysis with varimax rotation was used for extracting various dimensions of food and beverage service practices followed in Indian hotels. This led to mining of eight factors with 21 variables. These, together, could explain 72.424 per cent of variance in the studied practices which can be considered as good.

Table 2: Total variance explained

\begin{tabular}{|l|c|c|c|}
\hline \multirow{2}{*}{ Component } & \multicolumn{3}{|c|}{ Rotation Sums of Squared Loadings } \\
\cline { 2 - 4 } & Total & $\begin{array}{c}\text { \% of } \\
\text { Variance }\end{array}$ & Cumulative \% \\
\hline 1 & 2.800 & 13.331 & 13.331 \\
\hline 2 & 2.629 & 12.520 & 25.852 \\
\hline 3 & 2.124 & 10.117 & 35.968 \\
\hline 4 & 1.863 & 8.870 & 44.838 \\
\hline 5 & 1.699 & 8.088 & 52.927 \\
\hline 6 & 1.671 & 7.955 & 60.882 \\
\hline 7 & 1.241 & 5.909 & 66.791 \\
\hline 8 & 1.183 & 5.633 & 72.424 \\
\hline \multicolumn{4}{|l|}{ Extraction Method: Principal Component Analysis. } \\
\hline
\end{tabular}

First factor, food \& beverage control and staff qualifications, consisted of five variables namely Problem of missing K.O.T, For every order, K.O.T's are prepared, 
Separate K.O.T's are prepared for alcoholic drinks, Service staff is formally qualified for the job, and $F \& B$ auditing is done at the end of each day; with eigen value of 2.8 and can explain a variance of 13.331 per cent in the studied practices.

Shortage in bar \& staff training, was the second important factor which could describe 12.520 per cent of variance with an eigen value of 2.629 with five variables i.e. Speciality of the day is offered, Problem of shortage in Bar, You provide training to service staff, Staff is informed in advance about changes in menu, and Price of dish.

Table 3: Factors of food \& beverage service practices

\begin{tabular}{|c|c|c|c|c|c|c|c|c|}
\hline & & & & Compon & & & & \\
\hline & 1 & 2 & 3 & 4 & 5 & 6 & 7 & 8 \\
\hline F\& B Control and Staff Qualifications & & & & & & & & \\
\hline Problem of missing K.O.T & 0.849 & & & & & & & \\
\hline For every order, K.O.T's are prepared & 0.736 & & & & & & & \\
\hline $\begin{array}{l}\text { Separate K.O.T's are prepared for alcoholic } \\
\text { drinks }\end{array}$ & 0.656 & & & & & & & \\
\hline Service staff is formally qualified for the job & 0.626 & & & & & & & \\
\hline F\&B auditing is done at the end of each day & 0.510 & & & & & & & \\
\hline Shortage in Bar \& Staff Training & & & & & & & & \\
\hline "Speciality of the day" is offered & & 0.724 & & & & & & \\
\hline Problem of shortage in Bar & & 0.666 & & & & & & \\
\hline You provide training to service staff & & 0.612 & & & & & & \\
\hline $\begin{array}{l}\text { Staff is informed in advance about changes in } \\
\text { menu }\end{array}$ & & 0.587 & & & & & & \\
\hline Price of dish & & 0.534 & & & & & & \\
\hline Menu and Decor & & & & & & & & \\
\hline Changes in menu takes place & & & 0.720 & & & & & \\
\hline Menu analysis & & & 0.707 & & & & & \\
\hline Décor of restaurant & & & 0.524 & & & & & \\
\hline Crockery and Cutlery & & & & & & & & \\
\hline Quality of crockery and cutlery & & & & 0.877 & & & & \\
\hline Variety \& Waste Management & & & & & & & & \\
\hline Variety in menu & & & & & 0.757 & & & \\
\hline Waste management policies & & & & & 0.644 & & & \\
\hline Consider nutritional value of menu items & & & & & 0.536 & & & \\
\hline Availability of Items \& Portion Size & & & & & & & & \\
\hline Listed menu items are available & & & & & & 0.866 & & \\
\hline Standard portion size & & & & & & 0.711 & & \\
\hline Restaurant layout & & & & & & & & \\
\hline Restaurant layout affects productivity & & & & & & & 0.819 & \\
\hline Menu layout \& Design & & & & & & & & \\
\hline Menu layout \& design & & & & & & & & 0.904 \\
\hline $\begin{array}{l}\text { Extraction Method: Principal Component Anal } \\
\text { Rotation Method: Varimax with Kaiser Norma }\end{array}$ & & & & & & & & \\
\hline
\end{tabular}

Third factor comprising of, Changes in menu takes place, Menu analysis and Décor of restaurant, a total of three variables, was named as Menu and Decor; could explain 10.117 per cent of variance with an eigen value of 2.124.

Quality of crockery and cutlery was the sole variable in fourth factor with an eigen value of 1.863 and was responsible for 8.870 per cent of variance in the studied practices.

Variety \& waste management was the fifth largest dimension consisting three variables i.e. Variety in menu, Waste management policies, and Consider nutritional value of menu items with an eigen value of 1.699 and ability to explain 8.088 per cent of variance for the study.

The sixth factor was named availability of items \& portion size as it has variables such as listed menu items are available, and standard portion size which are accountable for 7.955 per cent of variance and an eigen value of 1.671 .

The last two factors, i.e. seventh and eighth, named as restaurant layout and menu layout $\&$ design had one variable in each for example Restaurant layout affects productivity and Menu layout \& design. The seventh factor was responsible for 5.909 per cent of variance with an eigen value 
of 1.241; whereas the last factor was liable for 5.633 per cent of variance with an eigen value of 1.183.

\section{Discussion}

Food and beverage service is one of the main revenue producing departments of a hotel. So to determine different important practices related to food and beverage service, factor analysis was performed and the results were presented in previous section. It can be concluded that various activities related to food \& beverage control, e.g. preparation of K.O.T.'s, missing K.O.T.'s, auditing of food and beverage stores, and formally qualified staff are of prime importance for better management of food and beverage service practices in sampled hotels. The respondents were of opinion that the concept of 'speciality of the day' should be introduced in menu; and problem of shortage, particularly in Bar, was of much concern for hoteliers. It was clear from analysis that the hotels understand the importance of training and timely information of changes in menu to service staff. There were also serious concerns about the price of dishes in menu. However, layout of restaurants and menus were not given much attention by the hoteliers; and menu designs were found to be least affecting the food and beverage practices in sampled hotels.

\section{Conclusion}

In a hotel, food and beverage service department is responsible for menu planning, serving, control, staff training, hygiene, restaurant layout etc. Researchers have found that these have contributed to the better management of food and beverage serving practices in hotels. These can help a hotel in outsmarting its competition and earn huge profits. Therefore, this study tries to disclose different factors that affect food and beverage service practices in sampled hotels of India. The data was collected with the help of a 5 point Likert Type scale from the food and beverage service managers or supervisors. Factor analysis was used to reduce several variables of the study into fewer dimensions and to study the importance of various food and beverage service practices. It can be concluded on the basis of findings that various activities related to food \& beverage control, e.g. preparation of K.O.T.'s, missing K.O.T.'s, auditing of food and beverage stores, and formally qualified staff are of prime importance for better management of food and beverage service practices in sampled hotels. The findings shall prove to be very helpful for better management of food and beverage service in hotels; though, the main limitations of the study are the universe and sample size.

\section{References}

1. Aaron Allen \& Associates (2017). Why India's Foodservice Industry Is one of the Fastest-Growing in the World?

2. Amlani, R. (2016) NRAI Report

3. Avery, A. C. (1968). Simplified, Food Service Layout. Cornell Hotel and Restaurant Administration Quarterly. 9. pp. 114119.

4. Bernatsky, M. (1971). Trouble-Shooting Food and Beverage Operations. Cornell Hotel and Restaurant Administration Quarterly. 12. pp. 109-118.
5. Cousins, J. (1988). Curriculum development in operational management teaching in catering education. The Management of Service Operations, Johnson, R. (ed.), Bedford: IFS Publications, pp. 437-59.

6. Cousins, J., Foskett, D. and Gellespie, C. (2010). Food and Beverage Management, 2ed. Pearson Education Inc. Delhi.

7. Cracknell, H. L., Kaufman, R. J., and Nobis, C. (2000). Practical Professional Catering Management, London: Macmillan.

8. Davis, B., Lockwood, A., Pantelidis, I., and Alcott, P. (2013). Food and Beverage Management, 4 e, Routledge, Delhi.

9. Ghene, J. A. and Nejelski, L. (1970). Food Service Systems: Human Factors in Administration. Cornell Hotel and Restaurant Administration Quarterly. 11. pp. 49-56.

10. Gunnar, P. M. and. Burkhart, J. A. (1977). Food and Beverage Operations in the Condominium Hotel. Cornell Hotel and Restaurant Administration Quarterly. 18. pp. 66-68.

11. Hubsch, A.W. (1966). Cornell Hotel and Restaurant Administration Quarterly. Hotel Food and Beverage Management. 7. pp. 9-11.

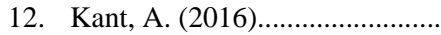

13. Kotschevar, L. H. (1965). Food Service Equipment and Jobs. Cornell Hotel and Restaurant Administration Quarterly. 6. pp. 70-73.

14. Lambert, C. U. and Watson, K. M. (1984). Restaurant Design: Researching the Effects on Customers. Cornell Hotel and Restaurant Administration Quarterly. 24. pp. 68-76.

15. Lundberg, D. E. (1994). The Hotel and Restaurant Business ( $6^{\text {th }}$ ed.). John Wiley and Sons Inc. Haboken. New Jersey.

16. Malik, S. and Kumar, S. (2012). Factors Affecting Menu Planning In Hotels: A Study of North India. Innovative Journal of Business and Management. 2012;1:6:97-101.

17. National Restaurant Association. Pocket Facts. 1999.

18. Palmer, J., Kasavana, M. L. and McPherson, R. (1993). Creating a Technological Circle of Service. Cornell Hotel and Restaurant Administration Quarterly. 34. pp. 81-87.

19. Patterson, J. and Alvarez, R. (1985). Computer Systems for FoodService Operations. Cornell Hotel and Restaurant Administration Quarterly. 26. pp. 132-141.

20. POSIST (2018) Restaurant Trends that will Shape the Indian F\&B Industry in 2018!

21. Powers, T. F. (1976). Food Service in 1985. Cornell Hotel and Restaurant Administration Quarterly. 17. pp. 40-54.

22. Romanelli, F. (1978). Energy Management in Food Service Systems. Cornell Hotel and Restaurant Administration Quarterly. 19. pp. 4-5.

23. Shiring, Sr., S. B., Jardine, R. W. B. and Mills, Jr., R. J. (2001)Introduction to Catering: Ingredients for Success. Delmar, a part of Cengage Learning, Delhi

24. Walker, J. R. (2009). Introduction to Hospitality Industry (6 ${ }^{\text {th }}$ $E d$.). Pearson Education Inc. New Delhi.

25. https://www.franchiseindia.com/restaurant/Restaurant-Sectorto-grow-aggressively-in-India-Indian-Restaurant-Congress2017.9970

How to cite this article: Malik S. Food \& beverage service practices: A study of small hotels in India. J Manag Res Anal. 2018;5(4):442-446. 